\title{
I Was Learning Economics at the Cost of the Economy $^{*}$
}

\author{
Majumder Debasish \\ University of Calcutta, Kolkata, India \\ Email: debmaj6972@gmail.com
}

How to cite this paper: Debasish, M. (2021). I Was Learning Economics at the Cost of the Economy. Theoretical Economics Letters, 11, 615-642. https://doi.org/10.4236/tel.2021.113041

Received: April 28, 2021

Accepted: June 26, 2021

Published: June 29, 2021

Copyright $\odot 2021$ by author(s) and Scientific Research Publishing Inc. This work is licensed under the Creative Commons Attribution International License (CC BY 4.0).

http://creativecommons.org/licenses/by/4.0/ (c) (i) Open Access

\begin{abstract}
COVID-19, a virus of the size of 0.12 microns, had crippled the global economy with 19.14 million people infected as of April 15, 2020, increased to 37.11 million as of October 11, 2020 as per the COVID-19 Weekly Epidemiological Update published by World Health Organization (WHO). The COVID-19 count as of March 23, 2021 was more than 122 million, suppressing the last year's rate of growth of the same. Economic activities across the globe had been stalled after February 2020. The world has been caged in a Great Lockdown. For the vast majority of people, this has been the biggest economic upset of their lives. There were many causes of recession delineated in the contemporary research papers. Nevertheless, too many causes of the crisis, too many research papers, so many techniques for optimization and too many surveys, etc., frequently divert the focus. We should not lose focus in the sea of numerous causes of recession. Therefore, the objective of the present paper is more specific: "Was conservative/defensive stance in the risk management in the regulatory policymaking post-global financial recession (2007-10) foreboding or worthy?". The subprime crisis of 2007-08 and the economic recession that followed and many significant economic and socio political events after 2010, e.g., the sovereign debt crisis in Greece, European credit crisis, Brexit, the Venezuelan hyperinflation in 2014, China-United State trade war (July 6, 2018-present), etc., had left many economists on the defensive stance in the policy research/policy prescriptions. We can't deny that scholars belonging to pre- and post-global financial crisis (2007-2010) generally possessed opposite views. For example, Berkowitz and O'Brien (2002) argued that 99th percentile VaR forecasts were conservative; however, recommendations by the BASEL committee of banking supervision (BCBS) since 2010 were 99th and 99.9th percentile VaR forecasts. It is difficult to judge if economic policies post-global financial crisis were impartial or for
\end{abstract}

${ }^{\star}$ Views expressed in the paper are those of the author and do not represent the views of the organisation that the author belongs to. 
espousing a specific interest group/lobby. It is furthermore difficult to speculate if economic policies after 2010 were influenced by the great recession (2007-10)'s debilitating impacts.

\section{Keywords}

Aggressive/Unconventional Monetary Policy, Value-at-Risk (VaR), Nowcasting

\section{Introduction}

"I am death, your mother, from me you will get new birth"1. "Your mother" could be "The Mother Earth". The disease borne by the virus called COVID-19 has been spreading swiftly like an unfriendly ghost, and, unlike epidemics of the past 1000 years, the epidemic caused by the outbreak of COVID-19 pandemic is due more to its spread rather than its severity. I quote from Gopinath (2020a), "The economic recession consequent upon the COVID-19 pandemic and universal lockdown has been the deepest since the Great Depression of the 1930s". On one hand, a large number of human lives got lost, and, on the other, the disruption in the ecosystem of financial services was unprecedented. For the vast majority of people, this has been the biggest economic upset of their lives. Fear of diseases and uncertainty in livelihoods resulted in widespread anxiety, rage and misery. You feel anxious, yet you cannot complain. Whom do you complain to when everybody is in panic? Arguments and counterarguments would multiply anxiety and the solution set remained void. The magnitude and speed of collapse in economic activities and its domino impacts were of unimaginable proportions and therefore the event was a rare economic disaster (Mishra, 2020; Gopinath, 2020a). In economics, a rare disaster is a collapse that is infrequent and large in magnitude, having widespread negative impacts on an economy with strong contagion effects. With the spread of the disease, panic swept over financial markets, financial institutions and business firms, temporarily paralyzing economic activities. Financial market prices across Europe, America, Asia and Australia went into a tailspin after February 2020 and many business organizations had been struggling with acute short-term stress in terms of limited access to credit, higher cost of funding amid disruption in normal cash flows and the working capital cycle of the business.

Paul Samuelson had commented on the global financial crisis (2007-10), "What we know about the global financial crisis is that we don't know very much". This was equally true regarding the disaster of 2020-21. The economic crisis of 2020-21, like no other economic crisis on earth, had not been foretold/predicted by any economist/professional/market researcher. The economist and policymaker, Raghuram G Rajan, discussed the structural weaknesses present in the world economy

${ }^{1}$ A quotation of Rabindranath Tagore. 
and warned about the growing risks in the financial system in his book, Fault Lines (2010), and at the Federal Reserve annual Jackson Hole conference in 2005. A historian and influential newspaper columnist, Niall Ferguson, in his seminal book, The Ascent of Money (2008), had predicted the forthcoming recession of 2008-10. The questions were: "Why was the disaster of 2020-21 not foretold/ predicted by any scholar?" and "What did we learn from the experience?". The rest of the paper is organized as follows: Section 2 illustrates a recent debate between two economists. Section 3 revisits policies during 2010-2021 followed by conclusions and recommendations.

\section{A Debate between Two Economists}

In March 2021, a debate on the topic, "COVID-19: Impact on the Economy and impulsive growth" was organized by the University of Calcutta participated by Prof. Neeta Majumder and myself. The event was awesome as it brought to light the situation of economic recession consequent upon the COVID-19 pandemic and the universal lockdown. The veteran economist and an expert in analyzing risks evolved out of extreme events, Prof. Neeta Majumder, was invited to that event. The transcript of the debate between Prof. Neeta Majumder and Prof. Debasish Majumder is given below:

Prof. Neeta Majumder (Date: March 31, 2021, Time: 9AM):

Good morning everybody. I warmly welcome you all to the debate on, "COVID19: Impact on the Economy and impulsive growth", organized by the University of Kolkata.

Prof. Debasish Majumder (Date: March 31, 2021, Time: 9.05AM):

I welcome research scholars, junior faculties and other invitees and also wish to thank the organizers for hosting this great event, undeterred even during this stressful situation of COVID-19 pandemic and prolonged lockdown.

Prof. Neeta Majumder (Date: March 31, 2021, Time: 9.10AM):

Significant advancements in economic theory are often ushered in conditions of whirlwind change. Blame to others as creators/leaders of the crisis is the worse part, rather good that as modern philosophers and economists asserted that they have never seen such a flurry of change as that unfolded over a year and there is a great scope for innovation. The crisis began with a deadly disease since February 2020, triggering a severe contraction of the real economy that was rapidly disseminating across economies. It has not only wrecked our health and sanity but also left quite a lasting impact on our lives. For the vast majority of people, this has been the biggest economic upset in their lives. After February 2020, people around the globe had experienced curfew, self-curfew, lockdown, nakabandi, protest, sexual harassment, alcohol addiction, etc. Newspaper editors were frequently using quotations by legendary economists, policymakers, novelists, scientists, statesmen to describe the negative impacts of those events. Charles Dickens's "A Tale of Two Cities" was purposefully framed by an editor of a reputed newspaper as "A tale of political offense", "A tale of severe alcoholism", "A tale 
of love jihad". These three terms were found in three different day's publication of a leading English newspaper ${ }^{2}$ in India during April 2020. Some odd terms, which had infrequent usage generally, were commonly found in newspapers during the period of great lockdown: "the conflagration of fury", "overzealous judicial intervention and subsequent collapse of law", "fear of contamination", "sexican", "filthy", "fake news", "data cooking", "unfair trade practices", "verbal violence", "serious tussle between interest groups", "aggressive/unconventional policy", "mafia democracy", "rig ratings", "hyper obsession", "attacked by a superspreader of online smears", "data leak in the government's mobile app", "alcoholism", etc. Some odd events, which were infrequent generally, had been frequently reported in reputed English dailies: a junior leader filed an FIR against a cartoonist for the odd drawing of pictures of the senior leader. The cartoonist stated in the court that it was his profession to draw humorous cartoons. Policemen arrested a few young intruders. Mighty policemen's initial intuition was that young men did not have taken COVID-19-related precautions (viz. COVID-19 masks, etc.), alcohol addict and flouted instructions of law enforcement authorities. Catching those COVID-19 pandemic intruders was not an easy task and not cost-effective also. Therefore, sophisticated CCTV set-up, active policemen with new uniforms for monitoring constantly criminal acts were required. The police department demanded wage-escalation for specialists and also stimulus packages due to exigencies arising out of COVID-19 pandemic and great lockdown.

Prof. Debasish Majumder (Date: March 31, 2021, time: 9.45AM):

Economics is the subject centering around conflicts between two opposite schools of thought, namely "classical-Keynes controversy", "neoclassical-Keynes controversy", "Keynes-monetarist controversy", "mordanist-primitivist controversy", "formalists-substantivists controversy", etc. I do not agree with the school of thought of Prof. Neeta Majumder. It was implicit in her speech that the government expenditure had increased because of more salary and stimulus packages sanctioned to the police department's specialists. Whatever got sanctioned for the above purpose would perhaps be a minor percentage of the national income of the country.

Prof. Neeta Majumder (Date: March 31, 2021, time: 10.05AM):

Under intensified public pressure to invent a vaccine for the deadly disease, the government and the central bank jointly took aggressive/unconventional policy stances for the purpose of bringing back the economy to a higher growth trajectory, i.e., pre-COVID-19 level of growth. However, there were conflicts among different interest groups. A rival lobby (or rival interest group) claimed that new inventions and discoveries that are shaping our modern world could be traced back through the centuries and even beyond. Any invention, either scientific-technological or socio-political or vaccine is a creative process. New ideas and concepts behind a revolutionary invention are gifted by the GOD. There-

${ }^{2}$ The name of the newspaper is not disclosed. 
fore, inventions are always uncertain. Unfortunately, sometimes they require gigantic funding. The rival interest group further asserted that aggressive/unconventional stances for monetary policy were viewed as norm-bursting before the great lockdown, turned conventional afterward (Kennedy \& Dodge, 2020). It brought to the fore tussles among senior economists/practitioners/market researchers that intensified conflicts among political groups with different schools of thought. I quote from Bulletin, Reserve Bank of India (2020b), "Unprecedented policy offensive was launched on the platform of extraordinary monetary policy accommodation in which the policy repo rate has been lowered by 115 bps since March 2020, taking the size of cumulative rate cuts to $250 \mathrm{bps}$ since February 2019. In the event, the entire term structure of interest rates has softened in sync with the monetary policy stance, and liquidity constraints have been dissipated before they could morph into solvency concerns in the financial system". Mishra \& Rajan (2016), however, argued that aggressive monetary policy actions by one country could produce significant adverse cross-border spillovers. The unconventional "quantitative easing" policy for the purpose of boosting the confidence of consumers, aggressive merger of banks for the purpose of reducing banking sector's non-performing assets, aggressive tax reforms, aggressively canceling registrations of banks/Non-Banking Financial Companies (NBFCs) adopted by policymakers of many emerging market countries had significant adverse impacts on the domestic economy and also had adverse spillovers to emerging market peers.

Aggressive/unconventional monetary policy is not a friend, but an adversary, from the standpoint of boosting demand. I am surprised when central banks of many developing economies took aggressive/unconventional monetary policy stance but the time gap between two such consecutive policies amid the great lockdown was less than two months. It is similar to think that the time gap between heavy breakfast and heavy dinner was less than 8 hours. Although a workable nutritious meal has been taken in the lunch, dysentery occurred. A student in the master's in economics class had questioned me, "Madam, why policymakers in the central bank of emerging market economies have not given adequate time for transmission of monetary policy impulses to the real economy?". I was little diplomat in answering him that a policy is being formed standing at time $t$, but it is critical to differentiate among policies, programs and policy actions. I always take recourse to Milton Friedman's "long \& variable lags" in the transmission process. It was, however, difficult to forecast the exact lag. However, it was also a fact that scholars reported misestimation and abnormal movements in macroeconomic indicators after 2018 and policymakers in the emerging market economies were frantic to bring back the economy to the pre-COVID-19 growth trajectory. Undeniably, since February 2020, when financial markets were moving by animal spirits and not by reasons, a stable statistical relationship between the nominal anchor and the price level was hard to establish (Choraia \& Das, 2021; Correa, 2020; Subramanian, 2019). Scholars be- 
longing to the pre-and post-global financial crisis (2007-2010) commonly possessed different views on the risk management policy of an institution. For example, Berkowitz \& O'Brien (2002) argued that 99th percentile VaR forecasts were conservative, however, recommendations by the BASEL committee of banking supervision since the year 2010 were 99th and 99.9th percentile VaR forecasts (Majumder, 2016, 2018). Unfortunately, on some occasions, the conservative choice of the tolerance level calibrated substantially high market risk capital, which would not have been supportive of the institution's profitability.

Often, too many techniques for optimization, so many algorithms for forecasting available in statistical computing packages, confuse present-day policymakers to choose the best among many. "Nowcasting" is a modern approach that helps in the quick prediction of important macroeconomic indicators, whereas forecasting methods are backdated as they require a large volume of historical data to estimate. Over the last three years, therefore, the policy researcher's interest was centering around nowcasting methods which are simplified approaches and by and large generate correct results helping the subordinate to submit the report to the boss within a short span of time. Unfortunately, the opponent interest group commented that these methods are simplified heuristic approaches and have an avenue to manipulate information by the policymaker. Policies implemented based on nowcast models without stress tests were cleverly described by the opponent group as "guesstimation" or the method that uses "guess and estimate". The opponent group's attitude was like a clever fox who was seeking political advantages in an interesting political game. I asked one of my leader friend $^{3}$ who was of age 70 and was in opposition trying to get more seats in the next election: "Sir, you are above 70 and now you are also infected by the deadly disease, how do you serve for the nation?" He replied, "You are right, Professor, I am not only infected by COVID-19 but also having severe stomach infection and constipation. At this moment, it is not possible for me to serve for the nation and I need special treatment from doctors. However, I promised while taking oath as a chief minister eight years ago that I serve for the nation and this promise is my 'sakti'. When I serve for others, I feel the same zeal as it was in the day of oath and more importantly, sir, after recovery, I have to attend two important summits to be happened in abroad in next six months". I felt he was sufficiently weak at this moment but salute to his zeal.

Prof. Debasish Majumder (Date: March 31, 2021, time: 10.50AM):

Now-casting models exploit information/data which are published early and possibly at higher frequencies than the target variable of interest in order to obtain an "early estimate" before the official figure releases (Bańbura \& Giannone, 2013). This class of models is relevant in economics because key statistics on the present state of the economy are available with a significant delay. Because in emerging market economies, after the global financial crisis (2007-10), policymakers were more concerned about the macroeconomy, legitimate requirements

${ }^{3}$ The name of the leader is not disclosed. 
of the number of meetings for framing monetary policy had been increased significantly. Present-day policymakers had to trust too much on now-casting techniques compared to the previous generation for predicting GDP subcomponents, oil price and subcomponents of the price index.

Prof. Neeta Majumder (Date: March 31, 2021, time: 11.05AM):

Thank you, Prof. Majumder. But, sir, critique said that the nowcasting depends on guess and so ideally these methods should be used when no better method is available. Too many policy actions based on nowcasting techniques would be criticized in circumstances when the speed and quantum at which the central bank's policy rate changes passes on to the real economy was indeterminate (Singh, 2019). Over the last three years, a trend has been developed not to explore the forecasting results because of legitimate requirements of escalated number of meetings. The opponent interest group cleverly called policies implemented based on nowcast methods as "politicalized implementation".

Non-Performing Assets (NPAs) accumulated over time was a critical issue for the emerging market bankers in the aftermath of the global financial crisis (2007-12), which could not be resolved through traditional regulatory and supervisory measures or traditional ways of policymaking. In some cases, the central bank and the government jointly took initiatives to resolve NPA problems by injecting capital into the banking sector, providing financial support such as stimulus packages, strengthening regulations, and improving the monitoring system. India was a prominent example in this group (Nachimuthu \& Veni, 2019). Unfortunately, instead of amelioration, the problem got aggravated. In India, the NPA to GDP ratio has escalated and reached an unmanageably high level in the first quarter of 2020-21. After March 2020, it was almost difficult to assess the exact magnitude of NPAs and also total deficits in the banking sector for this country. In some emerging market countries, conservative norms for recognizing income and asset quality were employed post-global financial recession, and simultaneously compliance for adherence to those regulations has been tightened. In some other countries, non-compliance has long been substantial, and the government/regulatory authority occasionally exercised discretion in imposing penalties, cancellation of registration and other punitive measures. The critic may question: 1) Were conservative norms influenced by the debilitating impacts of the previous recession?, and 2) We cannot deny that with regulatory compliance directives and discretion in awarding punishment conjointly would be unjust policies. If so, then was the government/regulatory authority biased and partisan?

It was observed that public sector companies had frequently availed trade credit. The origin of the financial instrument goes way back and is the loan extended by trade credit organizations to companies when goods and services are bought on credit. This contract is commonly used by business organizations as a source of short-term financing. Unfortunately, after the global financial recession (2007-12), non-payment of accumulated dues/EMIs related to trade credit 
by public sector companies to their suppliers, and simultaneously stringent regulatory measures by the government/the central bank/sectoral regulators/lawmakers introduced fragility into the sector. The moral hazard prompted by the government that occurred in this form was critical and hard to understand. On some occasions, the moral hazard by the government was in different forms. In economics, the issue is one among the most complex topics, and also occurrence such phenomenon is rare. However, the event could have a widespread effect that may lead to a fall of the nation. It occurs in circumstances when there is an incentive to increase in government exposure to risks by exploiting higher degrees of regulatory measures/legal measures/use of government's safety net/the use of fuzzed or manipulated data/rig rating for the purpose of getting murky benefits. In the post-COVID-19 regime, the moral hazard by the government was also in providing support in a discretionary manner. Support/help could be in the form of subsidies/capital injection/land to Special Economic Zone projects/tax waving/relief or help related to COVID-19/helicopter money as an anti-deflationary measure. Often in-group cooperation, in-group favoritism and also in-group fiscal support were provided through unclear bureaucratic communications, viz., office noting, gazette, circulars. Opaque bureaucratic communications were hard to interpret correctly by the illiterate or semiliterate CEOs/directors/heads belonged to the opponent interest group. Sometimes it was hard to overcome technical glitches, and as a result, they obtained no benefits. The bureaucratic game was designed by the leaders as they knew members of the board of directors of cooperative banks/NBFCs/small and micro scale startup companies formed by out-group members were generally illiterate or semiliterate, whereas the same for public sector enterprises were literate. Unfortunately, in spite of many good deeds, leaders had bad reputations due to their in-group bias. Nonetheless, fiscal supports to influence an economy was not beneficial in the capitalist system, rather incentive-based schemes/risk-sharing strategies might be workable better and should be explored further.

There is a proverb that a company can go bankrupt but a nation cannot. However, when an economy experiences stagflation as in Kenya in 1979-80, or the domestic currency is devalued to an extremely low level as the Venezuelan bolivar in 2007, or the Sierra Leonean leone during June 2016 to December 2020, causing chaos in financial markets, hyperinflation, shortages of basics goods and generates high-order financial stress. The economy had collapsed due to malign influence of a broad range of prodigal factors, prolonged depression with high bankruptcy, high unemployment, wiping out the value of the investments and reserve, trigger deceitful practices, viz., exploitation of the law to breach financial contracts, moral hazard, financial infidelity, etc., which leads corrosion of moral values of citizens and causes the fall of a nation due to Economic collapse (Schluter, 1994; Hausmann, 2014). Sometimes, uncertainty and wrong signals were prompted by the government by way of publishing macroeconomic indicators, graphs, and ratios in social media/newspapers in a manner that macroeconomic 
fundamentals of the country were incorrectly presented. China's stock market index looks good with the naked eye. However, if a statistician researches the data's statistical properties and calculates elementary indicators like skewness, kurtosis, higher-order moments, etc., the results would be startling. Kurtosis of the Shanghai-SE index for the daily data during 20th December, 1990 to 16th February, 2017 was 151.05, whereas kurtosis of a univariate normal distribution is 3 (see Table 1).

In India, the provision coverage ratio of banks had shown a prominent rise during October, 2019 to November, 2019, and a renowned market researcher opined, "The banking system is now strong enough to face the economic challenges of the ecosystem. The banks will be in a position to support the growth in the economy to a greater extent" (The Economic Times, 2019). However, the statement was perhaps in the direction of acquiring populist advantages because the jump in the ratio was in fact the outcome of the capital infusion by the government during the period or earlier. The major reduction in the NPAs as reported in the leading newspapers at that time was perhaps due to higher provisions for bad loans. The cooperative banks' lobby accused the government and the Reserve Bank of India for injecting capital in a discretionary manner. Inflation expectation surveys in developing countries were frequently conducted among respondents who were mostly middle to lower class in socio-economic strata. Respondents from rural areas were functionally illiterate and also sometimes were unaware of the price movements in commodity and asset markets. They were frequently demoralized by junior leaders of political parties who worked for political gains and occasionally were impacted by the pernicious effects of alcoholism and post-recession financial misfortune. It cannot be denied that data collected by the government officials by filling up a detailed questionnaire from villagers was distorted by perilous factors.

"Essentially, all models are wrong, but some models are useful", a common aphorism in statistics, is well-known in the academic world as George Box quote. A model can be thought of as a simplified representation of a system or objects,

Table 1. Kurtosis based on return (percentage change) from daily closing stock indices during 20th December, 1990 to 16th February, 2017.

\begin{tabular}{cc}
\hline Country (index) & Kurtosis $^{*}$ \\
\hline India (Nifty50) & 10.11 \\
Brazil (BOVESPA) & 11.25 \\
Russia (MICEX) & 18.83 \\
China (Shanghai-SE index) & $\mathbf{1 5 1 . 0 5}$ \\
USA (Dow Jones Industrial Average) & 45.20 \\
UK (FTSE 100) & 12.29 \\
\hline
\end{tabular}

${ }^{\star}$ Kurtosis $=\mu_{4} / \sigma^{4}$ where $\mu_{4}$ is the fourth central moment and $\sigma$ is the standard deviation. Source of data: Bloomberg. 
either by using a tool as a system of mathematical equations or examining patterns in a data set by making assumptions about the data as well as the environment it was gathered in and applied to. Since no model is perfect, the modeler cannot obtain a "correct" model by excessive elaboration. However, he should not advertently select an odd model with unrealistic assumptions or an obsolete model or a model on account of drawing populist's advantages. For example, the dividend discount model for stock valuation used for the purpose of monetary policymaking in a few emerging market economies perhaps be the right model for an efficient market (Bulletin, Reserve Bank of India, 2020a). However, the same was a wrong model due to the model's impractical assumptions, particularly during a stressful scenario of financial markets. It is a fact that, during the great lockdown, when financial market prices were moving by animal spirits, and not by reasons, the fundamental assumptions behind the dividend discount model, viz., "dividends paid out are correlated to earnings", was an unrealistic assumption. Since 1960 many advanced models for pricing stock have been introduced and scholars after the year 2000 were skeptical in using the conventional dividend discount approach. Economics has quite an extensive role in a multitude of contexts, particularly in the distribution and the redistribution of wealth. Marshall's description of economics was "An engine for the discovery of concrete truth" (Marshall, 1890). Friedman had approvingly quoted the above description and insisted that the study of economics was not merely a mathematical game and that it should enable one to understand how the real world works. Different objectives, however, may lead to different treatments of the subject. However, if the objective of the economist is in the line of popularize a specific type of model at the wrong time or promoting a specific econometric technique when the need is to protect the economy from going deep into the crisis, the economics will generate negative utility instead of securing the social welfare of all economic agents. Economic models based on rationality assumptions are only for understanding movements of macroeconomic indicators and not for policymaking, specifically during a crisis time. Sometimes two high-powered regulatory bodies/policymakers had a tussle on modalities of or time for implementing a policy. For example, the clash between the Governor of the Reserve Bank of India and a bench of three judges comprising Justice Rohinton F. Nariman, Justice Aniruddha Bose, and Justice V. Ramasubramanian formed in the Supreme Court of India for re-examining the instructions/directives related to virtual currency trading in India. The justice bench had lifted the restrictions imposed in 2018 by the Reserve Bank of India (RBI) on banks/financial institutions regulated by the RBI on virtual currency trading on March 4,2020, on the stand that virtual currency trading has numerous advantages and also advanced economies did not impose a ban on the same. On the other end of the spectrum, RBI Governor argued that lifting the ban on cryptocurrency trading in a recessionary phase of the economy was an imprudent decision because of the following reasons: 1) cryptocurrencies are not legal tender in any jurisdiction and are unre- 
gulated digital currencies and therefore there are fair possibilities that trading of cryptocurrencies would promote illegal activities, such as money laundering, bizarre banned witchcraft game, etc., 2) treading of cryptocurrency will lead to a further rise of exchange rate volatility in a turbulent situation of markets, 3) the risk of unforeseen events will be escalated because there is a possibility that grey market (or dark market) for exchanging such currencies could be developed and 4) overall risk of the banking sector will increase. The event was described by financial newspapers of the country as a "policy paradox". After March 4, 2020, as per evidence collected from different newspapers in the next thirty days, it was observed noncooperative attitude between two leading policymakers of the country in the cases of implementation of other policies in respect of FOREX markets (Reference: The Hindu, Mint, Business lines during March 5, 2020 to April 4, 2020).

Competitions/conflict of interest was often fatal for the economy. Unfortunately, if something went wrong, it was easier to frame excuses in circumstances when citizens were by and large conscious of the virus, diseases borne by viruses and vaccination, and not in other issues. Sometimes it was observed two contradictory circulars, one was issued before the great lockdown and another has been issued hastily after February 2020 due to exigencies that evolved during the great event. However, leaders were extremely busy in chalking out action plans, arranging additional resources and healthcare-related issues and did not have enough time to review redundant circulars. However, minor matters could amplify operational risks by creating avenues of dispute/disagreement and disrupt the normal flow of business processes.

Prof. Debasish Majumder (Date: March 31, 2021, Time: 12.05PM):

Constructive criticism would essentially be the starting point of strategic thinking. I, however, do not subscribe to the school of thought holding that the government and the central bank predominantly responsible for the Great Lockdown of 2020 and the abysmal economic recession that followed. Macroeconomic modeling had has been a challenging task even before the proficient modeler. Theorizing economic ideas in an effective way would essentially depend on how good the underlying variables, with the relevant assumptions for construction of the model, apt with real-world phenomena considering factors like the statistical system for data collection and compilation, regime switch, institutional set-up, historical antecedents, and socio-geo-political characteristics, etc. Besides this, the modeler creates his own "subjective social reality" from his perception of inputs and value judgment. Paradoxically, despite of the fact that the society's utility is the sum of all economic agents' utilities, individuals' utility and social planner's utility are commonly not collinear.

Economic theory is based on the assumption that economic agents will make agreements (or contracts), sometimes informal agreements, sometimes formal agreements, for example, as we observe in the present day, a principal-agent contract, a wage contract, a land tenancy contract, a trade credit contract, an insur- 
ance contract, a leasing contract, an employment contract, etc. Around twelve thousand years ago, when humans first decided to give up their nomadic, hunter-gatherer lifestyle in favor of settlements in one place, they tried to form business for their livelihood. They interacted and designed agreements. These agreements (or contracts) were the set of rules/terms/responsibilities to carry out activities/business smoothly. The agreement (or the contract), when legally enforceable, a legally binding document, delineating the terms, the rights and the obligations, are maintained. The general rules of a contract state that parties involved in a contract have to meet its obligations under the terms of the contract and, in the case of a breach, the party breaching the contract has to compensate other parties for damages caused. If the contract could not have executed because of an unforeseen extreme event beyond the control of both the parties or "act of GOD", the performance of such a contract becomes frustrated i.e., it becomes complicated or implausible. This was further explained in the famous Surrey music hall case which was also known as judgment of Taylor v Caldwell (1863) (see McElroy \& Williams (1941)). Caidwell (Defendant) had entered into a contract with Taylor (Plaintiff) on June 1861, by which he agreed to let Tailor to have the use of The Surrey Gardens and Music Hall on four days, viz., June 17th, July 15th, August 5th, and August 19th, for the purpose of giving a series of four grand concerts. After the making of the agreement, and before the first day on which a concert was to be given, the Hall was destroyed by fire. The burning of the hall led to the impossibility of contract fulfillment. The contract was automatically frustrated. The doctrine of common law impossibility was established because a rare event rendered the contractual obligation impossible and radically changed the party's principal purpose for entering into the contract. There was no clause within the contract which allocated risks due to incalculable probabilities. The law of "common law impossibility" or "act of GOD" would perhaps be inapplicable for contracts during the prolonged lockdown, as in the case of Taylor v Caldwell. However, it appears that due to many odd hindrances evolved as tiny obstacles, albeit plenty in number, in fulfilling contractual obligations in public sector and private sector enterprises during the great lockdown, many agreements or contracts or MOUs rendered null and void and the economy had entered into a deep recession.

With the increase in complexity of insurance markets over the past twenty years and the introduction of many innovative insurance products, it has become extremely difficult for common investors to price the new complex insurance products. These insurance products are hybrid in nature and are also difficult to understand their payouts, premiums, claims ratio, loss reserve, etc. Many of them give investment benefits in investing in stock markets, securities/mutual funds, as well as accident and health-related benefits. I was motivated by a famous saying, widely attributed to Albert Einstein: "Everything must be made as simple as possible, but not one bit simpler". The idea it expresses might be the right expression and is relevant to address problems of the life insurance com- 
panies across developing countries that are keen on promoting hybrid products. An insurance agent in B.B.D. Bagh, Kolkata, was trying to convince a senior woman by saying that insurance products are always considered a safe heaven for investment in an uncertain time. The complex insurance product simultaneously provides double benefits, good investment returns as well as accidental and health insurance. He perhaps performed social services in the line of spreading financial literacy. But I wonder that the insurance agent typically was not forthcoming about the term premium, the primitive insurance profile of the company. According to game theorists, an insurance contract made by a widow can be thought of as a game among three interested players: Player 1 is the insurance agent. He works for the company as a third party and helps the customer only when he earns a commission. Player 2 is the insurance firm that tries its best to disprove the claim put up by the client. Player 3 is the widow who tries to produce all the correct and necessary documents supporting the claim. In this game, Player 2 maximizes utility only if Player 3 loses and vice versa. Player 1's lookout is the securing of the maximum commission from Player 2 and also to ensure that his client (Player 3) earns smart investment returns as well as accidental and health insurance benefits. The term premium does not carry a commission, and therefore there is an incentive on the part of Player 1 to hide or distort true information to Player 3. In turn, insurance agents must profit through hiding information or distorting facts to their clients. Insurance firms motivate moral hazard by promoting third-party agents and giving them lucrative benefits, sometimes offering a platform for business promotion on the company's website. During a period of increased market volatility as evolved as the debilitating consequences of COVID-19 pandemic and Great Lockdown, when the financial health of insurance companies was vulnerable, it would likely be extremely difficult to secure accidental benefits by a widow who is a legitimate insuree from an insurance claim on the company, enclosing required and certified documents within the stipulated time period. Requirements of documents in India, for example, are death certificate authorized by any gazetted officer or local leader, photos of the accident spot, police verification report, post mortem report if her spouse was not infected by COVID-19 or other deadly diseases, the AAdhar Card, Votar Card, PAN card, passport, etc., were phenomenally increased over last ten years which made difficult for the widow to submit her claim. The insurance firm has the right to advise closer certification and scrutiny of all documents and uploads the same on the company's website in smaller-sized PDF. Unfortunately, the widow gets thwarted by these bottlenecks, which were possibly created deliberately. I did extensive research on the document uploading system of insurance companies. "Capta" was in italics and a special type of text highlighter was used. It was extremely difficult to guess if the company had made it difficult to read by a senior person deliberately or it was done inadvertently. Partial breach of contract by player 2 (i.e., the insurance firm) was in the line of intelligently designing seemingly justified a number of odd bottlenecks under the knowledge 
that player 3 (i.e., the policyholder) will eventually be laid off when she would found it implausible to meet requirements by player 2 at her knowledge level.

A hidden breach of a contract could be the manner in which a sales executive repeatedly tries for self-interest to convince a customer to purchase a security or a credit card or take a pre-approved loan and the customer is convinced to do the same. After 2010 the phenomenon of sales executives, who used to cajole prospective clients into purchasing newly-launched financial products, assembling inside a branch of a bank in a metro city has been proliferated. I had visited a branch of ICICI Bank located in south Mumbai in 2012 with the objective of opening a public provident fund (PPF) account which would earn good returns as well as provides tax savings benefits. However, a sales executive at the branch had convinced me to purchase a ICICI Wealth Builder-II plan, a hybrid mutual fund, which was expected to dominate the PPF and other comparable financial products and also offer tax savings benefits. Paradoxically, the reality was far from what the sales executive said and it turned out that the performance of the ICICI Wealth Builder-II was extremely poor over the next seven consecutive years. In this case, the contract entered into by me can be thought of as a game among three interested players: Player 1 was the sales executive. He worked for the bank as a third party and intermediated between the bank and customers. Player 2 was the bank. I was Player 3. In this game, Player 1 (the sales executive) would maximize his utility when he earned a maximal commission, sometimes by hiding or distorting data/information. He showed charts to his customers whose visual representation was excellent and customers in the developing economies generally did not have enough financial literacy to study those charts based on fuzzed/cooked data. When I researched these diagrams, I found that all the graphs pertained to the best performing fund in the sector/industry and was not related to the fund that I had purchased. Player 2 (the Bank) induced moral hazard by promoting third-party agents (sales executives) and offering them lucrative benefits including a platform for business promotion inside the branch. Regulations by the central bank and the government prevent bankers from switching funds freely from their commercial banking halve to the mutual fund or trading halve and the insurance business halve. However, cleaver bankers are using informal roots for profit-making.

Violation of the contract could even be a stronger one when a party willingly uses legal instruments, e.g., cheques, loan guarantee, etc., for self-interest and exploits the other party by repeatedly dishonoring cheques and inviting for negotiation already deemed to have been null and void. They learned the art of bad faith negotiation which is a type of negotiation when a party pretends to negotiate, but secretly has no intention to compromise (Holsti, 1962). In developing countries, home buyers are generally middle class in the socio-economic strata whereas the seller (or the builder) is generally in the affluent class. I knew a reputed builder M/S Jaycee Homes Ltd in the western suburb of Mumbai had taken advance booking amount $30 \%-50 \%$ of the cost of a flat in a pre-launched 
project at Mira Road, Mumbai and the project could not have been accomplished due to a cash crunch in the company. In compensation, the builder had given post-dated cheques to its consumers/clients which were bounced when deposited in the bank. The cleaver builder had instructed beforehand to his banker for "stop payment". Subsequently, he had called the party for negotiation. He explained that the economy was in the recessionary phase of the business cycle and his company had made a loss in the previous six quarters. He had convinced his clients that legal procedures had always been complex and also fees to the lawyer are high in the recent time. For avoiding all these nagging issues, if he would accept a new post-dated cheque that would be a win-win solution for both the parties. The client had accepted this proposal. A day before the date of the cheque, an important phone call from the builder's office had been received by him expressing difficulties evolved recently due to the consequence of the COVID-19 pandemic and the lockdown announced by the state government. Again the builder invited him for a negotiation. He said that company's position was bad due to the unforeseen extreme event which was a rare disaster. Farther, it was an "act of GOD" beyond the control of both the parties. Therefore, a better alternative negotiation could be if the client accepts a plot at Hyderabad. The art of bad faith negotiation was that one party aggressively pursued a set of terms to the point where the other negotiating party must either agree or walk away. The client had no choice to accept the proposal. Alternatively, he had to go for a legal battle post-COVID-19 and the cleaver builder could say it was impossible to carry out the contract due to the Black swan event. The event was beyond the control of both the parties. The strange fact was that the value of the very plot was only $30 \%$ of the value of the cheque and also the plot was located in an unpopular place so that the client would likely not be able to sell that.

Great lockdown enforced an alteration in the workplace environment, shifting it from physical space to remote working and warranted reimagination of strategies. During this regime switch in work culture, though one enjoyed the luxury of attending meetings/conferences online, frequent reluctance and apathy to do work were observed among staffs/employees in general. We could find an attitudinal difference varied prominently vis-a-vis the age-wise construct of the staff. Government/Public sector employees beyond the age of 50 were numerically substantial and were frequently found terrified due to vulnerability regarding health issues of self, spouse, sons, daughters and other family members in the ambiance of uncertainty generated by COVID-19 pandemic and prolonged lockdown. Sometimes they seem reluctant to adopt official work based on a digital platform. Once, I happened to ask one of my subordinate staff working in my department in the Reserve Bank of India, Mumbai, "Sir, you were observed not to have attended office even for a day in the last five months since the announcement of lockdown on March 23, 2020". Unabashedly, he replied, "It's work from home environment, Sir, and I shall come only 'on request”'. After 15 days, incidentally, I met the same aged staff at Mahabaleshwar $(263 \mathrm{~km}$ away 
from Mumbai). I inquired of him, "Sir, work from home is applicable if you are staying in the same city". He replied, "Sir, I have come here to take care of my son's health issues". I could not understand why he had come to a beautiful tourist destination and a hill station to take care of his son's health issues. Perhaps hill station is an ideal place for practicing yoga/meditation, camps for which were observed to have mushroomed here and there. Paradoxically, salaries/parks of employees in the Government/Public Sector Undertaking (PSU) are mostly protected. In developing economies, employment contracts in public sector enterprises are informal contracts in the line that provision of penalty in contractual terms are unclear in the case the boss is disappointed with the unsatisfactory level of services and the subordinates is not fully loyal and have easy excuses for avoiding works. In the economic theory, the problem was depicted as a game between an efficient boss and an irresponsible subordinate who can fabricate many realistic excuses to shirk work. It was easy to rationalize an excuse in certain circumstances. When the subordinate would be able to prove that he was truly sincere but could not do justice to his work due to unavoidable and unexpected circumstances, the same could be seen as hidden unemployment. The inevitable hindrances during the great lockdown could be "technical problems in remote working or attending online meetings", "military cantonment camp/nakabondi/curfew/janata curfew", "medical emergencies evolved in respect of self/relatives/friends", "survey field visits/tour/transfer related hazards", "legal risks that could evolve on account of various exigencies", etc., which were difficult to be verified if done deliberately for avoiding works. It was furthermore difficult to distinguish if the hidden unemployment is the forced unemployment induced by the pandemic or due to the fact that employees were unfaithful and had many excuses for neglecting works. However, salaries and parks of unloyal government/public sector employees would have been a minor percentage of the national income and thus the adverse effect on the economy was not significant.

Prof. Neeta Majumder (Date: March 31, 2021, Time: 1.15PM):

I appreciate Prof. Debasish Majumder's viewpoint that the remuneration paid to unloyal government/public sector employees would have been a minor percentage of the national income, and thus the effect on the economy was not significant. In fact, the total remuneration paid to the government/public sector employees in many emerging market countries would have been a minor percentage of the country's national income. However, if there remains a large segment of the active workforce whose marginal contribution to the firm's profit is insignificant, the situation would distort the smooth-running of a business. The phenomenon was primarily observed in the government/Public Sector Undertaking (PSU), particularly during the time of prolonged lockdown after February 2020. The condition was the disguised unemployment in the sector, which caused financial fragility as a ripple effect in interdependent sectors, e.g., business, services and manufacturing sectors. 
It was observed that directors, heads of various departments, CEOs, leaders and top-notch bureaucrats were aged people (age above 50) and few among them were very old (age above 65) and some are more veteran. However, people of different age groups living in the same neighborhood had prominent diversity in nature, viz., sense of community and social cohesion, activity patterns, attitudes and lifestyles, behaviors and identity (Stolle \& Harrell, 2013; Wise \& Noble, 2016). Still, it remained opaque about how their activities, preferences and biases had been linked to the cognitive development of malign influence, which has disruptive consequences on the national income of an emerging economy, particularly during the stressful circumstances of the pandemic with a higher risk of health and finance. Seniors in their different roles were frequently observed terrified due to the bad effects of the prolonged lockdown and anxious about the health of self and dependents. If he was the head of the family, he worried about his family members' health. If he was a Director or Head of Department (HOD) or CEO of a company, he worried about the health of his fellow staffers/subordinates. If he happened to be a leader, he fretted about the health of his subjects/citizens. Some renowned physiologists were of the view that worry is an addiction, similar to dependence on nicotine, alcohol, cocaine, etc., and cause loss of consciousness (Fox, Tuit \& Sinha, 2013). According to Wikipedia, some other prominent old age characteristics are forgetfulness, loss of memory and behavioural sluggishness, etc. In some English novels/proses, these characteristics were depicted as virtue and somewhere these were depicted as negative characteristics of a human. For example, Robert Lynd, a renowned English author wrote, "But a man who is like a remembering machine is never a wise man". He argued, "Forgetfulness is a virtue because it shows that the absent-minded man is getting the most in life, and has no time for ordinary things to remember". He also added, "The present-day statesmen do not have the genius of memory and of intellect combined". Nevertheless, it is universally true that policies are mostly the outcome of an old mindset which is subject to many cognitive biases. If the senior is the head of the family, or a leader of a community, or the head of the Finance Department, all the policies announced during the Corona epidemic would focus on combating diseases or eliminating the effects of deadly viruses. I quote the statement by Shri Saktikanta Das, Governor, the Reserve Bank of India, who was at age 67, “The Reserve Bank of India (RBI) is perhaps the only central bank in the world to have set up a special quarantine facility with its officers, staff and service providers, numbering about 200 , for critical operations to ensure business continuity in banking and financial market operations and payment systems" (Mint, 2020).

In the initial phase of the pandemic, as suggested by the International Monetary Fund (IMF), Governments of many developing countries had provided unprecedented fiscal support to households, firms, and financial markets as a path of recovery. Chief Economist of the International Monetary Fund recommended: 1) stronger support using both fiscal and monetary policy, 2) flexible regulatory 
measures to cope with emergencies and curbing trade restrictions for certain products, e.g., medical supplies and medical goods and 3 ) require to do a cost-benefit analysis before implementing a policy (Gopinath, 2020a, 2020b). During debilitating consequences of the crisis, some issues were observed which had become fatal: 1) developing countries were reluctant to reduce trade restrictions and some countries even imposed stringent export restrictions on pharmaceutical ingredients and drug formulations for meeting up requirements of increased number of patients (The Economic Times, 2021; BusinessLine, 2020) and 2) senior leaders, top-notch bureaucrats and senior CEOs had frequently become myopic and restless that they didn't delve deep into the unplanned miscellaneous expenditures, e.g., transaction costs, costs of health vulnerabilities, costs related to transfers of officials, maintenance costs of unused properties or machinery which could not have been disposed off, bad debts which could not have been possible to give a third party for securitization, exploration costs during prolonged lockdown, escalated service costs, costs due to change of incompetent law enforcement officials and many other costs behind implementing a policy. Often, they were concerned with quick policy implementation with a deadline so the directions of IMF were not maintained. Frequently the deadlines were so strict that no research paper, no parallel run, no backtesting, no scenario generation, no stress testing, no case study analysis had been possible to be done. Sometimes small costs stated in 2), which were ignored or could not have been speculated at the time of implementing a policy, escalated during the time of prolonged lockdown and summed up to an enormous cost that had created deficits.

On the other end of the spectrum, young management graduates in the public and private sectors were more carrier-oriented. The students, who were MCQ brilliant, could answer most of the questions correctly in the stipulated time, got selected in the entrance examination or in the examination for the promotion in a banking firm. The same was not a problem yet. The problem started during the prolonged lockdown after February 2020, when we see careerist young bankers were too much after profits and customers reported grievances that greedy bankers turned to profit hunters even during the stringent situation of COVID-19 pandemic and the lockdown. Economic stress, uncertain markets, selection bias, and increasing risks in international investments frequently led the greedy young bankers to tilt in favor of corruption. For seniors, it becomes really hard to distinguish between corrupt and honest functionaries. If the morally bankrupt young bankers become a part of the top management/board of directors, corruption increases and also non-performing loans soar to heights beyond any control, resulting ultimately in bank failure with commensurate cascading impact on symbiotic financial entities. Therefore, age-specific cognitive bias, e.g., fear of the aged public sector bank employees and greed of their next-gen counterparts, induce inefficiency in the workplace creating fragility in the economy at large. This is a trap because, in the public sector, it is difficult for the boss to pu- 
nish an established under-performer by way of reducing salary or terminating job. Also it is equally difficult to prevent the young corrupt bankers from being a part of the top management of the bank or the Central Bank. Competitions among senior positioned bankers caused rivalry which could create reputational risks for the banking firm. To cite an instance, bad reputations were earned by a leading banker, the founder-cum-CEO of Yes Bank, Shri Rana Kapoor, who got many prestigious banker awards of the country, had a fierce fight with senior positioned officials/directors in the banking regulatory body. However, strangely, total income for Yes Bank increased substantially in 2019 compared to the previous three years, EBITDA was Rs. 28,252 Crore, reported PAT was Rs.1720 Crore as of March-end 2019. The very bank had distributed high dividends in the previous five years. The mysterious fact was that moratorium i.e., commencement or continuance of all actions and proceedings for the Yes Bank and short-term suspension of the bank's board was declared during the time of great lockdown.

Prof. Debasish Majumder (Date: March 31, 2021, Time: 2PM):

Sometimes it was observed that a company had maintained an address with the ministry's website as well as on the hoarding signboard and was doing online business in the post-COVID-19 era. However, mysteriously another person from some other company had occupied the place and was telling the customers, "My office has replaced his office". It was opaque if the CEO was giving rent/money to the third party for maintaining the hoarding signboard and the address with the ministry or, otherwise, the hoarding signboard/address was kept as it was before out of reluctance. Generally, people do not go for legal proceedings unless no conflict/dispute arises, and the company was making money unlawfully utilizing the address of the third party. In the situation of conflict, the legitimate procedure is: first, giving the legal notice, and second, filling the case. In such scenario, the same company would change the address maintained with the ministry and the hoarding signboard easily. This is a minor violation of the buyer-seller contract because the company was unlawfully utilizing an address of the third party. However, it is extremely difficult to understand that it was a violation of the contract. If understood, it is expected that the wise man will be reluctant to go for a legal battle for establishing the CEO's malfunction activities.

Sometimes parties signed a contract or Memorandum of Understanding (MOU) are semiliterate about the economic implications of the agreement. Manipulating highly sophisticated statistical techniques or programming techniques or networking techniques in an economic model for a background paper without being properly refereed may violate the basics which would have long-run negative impacts on the domestic economy or adverse spillover effects on other economies. Prof. Manisha Chakraborty, Indian Institute of Management, Kolkata had shared an experience that once she asked a business leader when she was the adviser of his firm, "Sir, you have obtained one-day stock price forecasts using a hybrid model with a jump-diffusion process along with Expected shortfall (ES) 
as the measure of risk in the place of 'beta' in your CAPM type pricing equation which was submitted by your consultancy firm to your client recently. But do you have any reference paper on this hybrid model?". He replied, "Madam, we work for the client. If we research on the validity or theoretical consistency then that would essentially be a redundant job. There is a possibility that the client will terminate the contract due to the reason that our consultancy firm was doing a redundant job. Afterwards any of our competitors may win the contract".

Prof. Neeta Majumder (Date: March 31, 2021, Time: 2.40PM):

Since March 2020, remote work has become normal and also the environment of meeting/conference has changed from in-person gatherings to a virtual platform. A virtual platform eliminates the need to travel, but the flip side is the reported occurrence of frequent technical glitches whose reality or artificiality one is not in a position to judge or ascertain. "Technical problems" could be an innovative, unlawful weapon for a conspired businessman. By a coincidence it happened to me to listen to a broker, Mr. Sharekhan, who had a small broking firm in the southern suburbs of Kolkata instructing his fellow staffers, "Payments should work with any QR code or UPI code or VPN and do marketing with "Kublaence". This "Kublaence" has the ability to copy entire google database". Mr. Sharekhan further added, "If a client inquires regarding big capital loss, your possible answer should be "mutual fund investment is subject to market risks' and the investor who cannot bear the risks, he or she should invest only in Government bonds". Unfortunately, it is extremely difficult to understand for a senior economist how the payment could be made with any QR code or UPI code or VPN and also I couldn't understand, "What was 'Kublaence'?". I guess it could be any software or package invented by Mr. Sharekhan. However, in this case, the expected loss in investing in a mutual fund was perhaps not due to market risks. If so, then how Mr. Sharekhan was so confident about the future capital loss in his client's investments and also was giving training to his fellow staffers on what they should say in the case of a massive loss. I was feeling frustrated with my traditional knowledge of economic modelling. With the recent progress in technology, automation, big data and massive computational power, some changes in economic theory done by market researchers/practitioners were ambiguous. The money supply was being regulated by some prodigal factors like "unsafe and unsecured payment gateways", "digital currency that is not issued or controlled by a central bank", "unhedged foreign currency exposures", "change in accounting norms", "low-documentation or no-documentation mortgage loans/credit card loans/personal loans", "shadow banking/chit fund", etc., and unfortunately, conspired Share Khan has extensive research with only these intoxicants of economic theory.

I refer two articles, Economist (2019) and The Times of India (2020), as examples of how "techno piracy" created digital disruptions in banking industry and also exposed the private information of 73 lakh customers in BHIM mo- 
bile payment app. On some occasions, it was observed that a company was acquired by another company in an all-cash deal. But the question was: "Why the high-valued deal was in an all-cash deal?” For example, Reliance Brands, a subsidiary of Reliance Industries had acquired British toy-maker, Hamleys, in June 2019 in an all-cash deal. Illegal activities have been legalized by various means namely unlawful complaints related to health and sexual harassment which were not possible or difficult to verify. Sometimes it was observed that the board of directors were formed not through fair means but by some odd unlawful means like "hiding of facts/information", "verbal violence and unlawful legal proceedings", "documents and bureaucratic malfunctioning", "technical problems which cannot be checked or verified", "unlawful complaints related to heath and sexual harassment", "techno piracy", "spreading rumor through social networking sites/newspapers", etc. Sometimes it was found that unethical leaders legalize illegal issues in various ways. They reduce product prices by means of offer/lottery with the objective of increasing the consumer base. However, the deficiency in the income due to reduction of product prices is makeup by unethical means like piracy, phishing, hacking, etc. However, conspired acts like piracy, phishing, hacking, etc. may attract severe punishments. Entrepreneurs manipulated many strange innovative ways which generate off-balance sheet earnings. For example, sending paid small bills repeatedly to customers in the conspired hope that if the customer does not preserve old documents and pay the small outstanding perfunctorily. Sometimes it was observed that if levy charges, viz., financial charges and late payment charges, were imposed in a month, the same is being continued in the electronically generated credit card statements month after month unless the customer actively sorts out these system-generated hazards. Figure 1 reports wrong levy charges in the Standard Chartered credit card statement. An email received from the Bank indicates, "Please note that charges on your card account are processed electronically, without any manual intervention. Hence we are unable to stop levy of charges on your card account in case of non-receipt of payment as per the payment schedule".

Sometimes sending a legal notice to customers for small disputed outstanding in the objective that if the same would have preferred to pay to avoid a legal conflict. However, the interesting thing was that these activities were not conspired activities as per the prevailing legislative system, but indeed were pernicious activities that created an unethical image in the mind of young subordinates about their senior boss. Unethical actions or behavior by respectable positioned people like CEOs, directors, leaders, bureaucrats, doctors and teachers produced depression among the ethical group of people. They think it is a dangerous phenomenon about the economy that less experienced young people have started to create their own "subjective social reality" from the malicious actions of unethical leaders. Ethical seniors were confused on the question, "How can we deal with this widespread corruption?". The economic recession of 2020-21 may be termed as "vicious cycle of worry, depression and unethical behavior". 


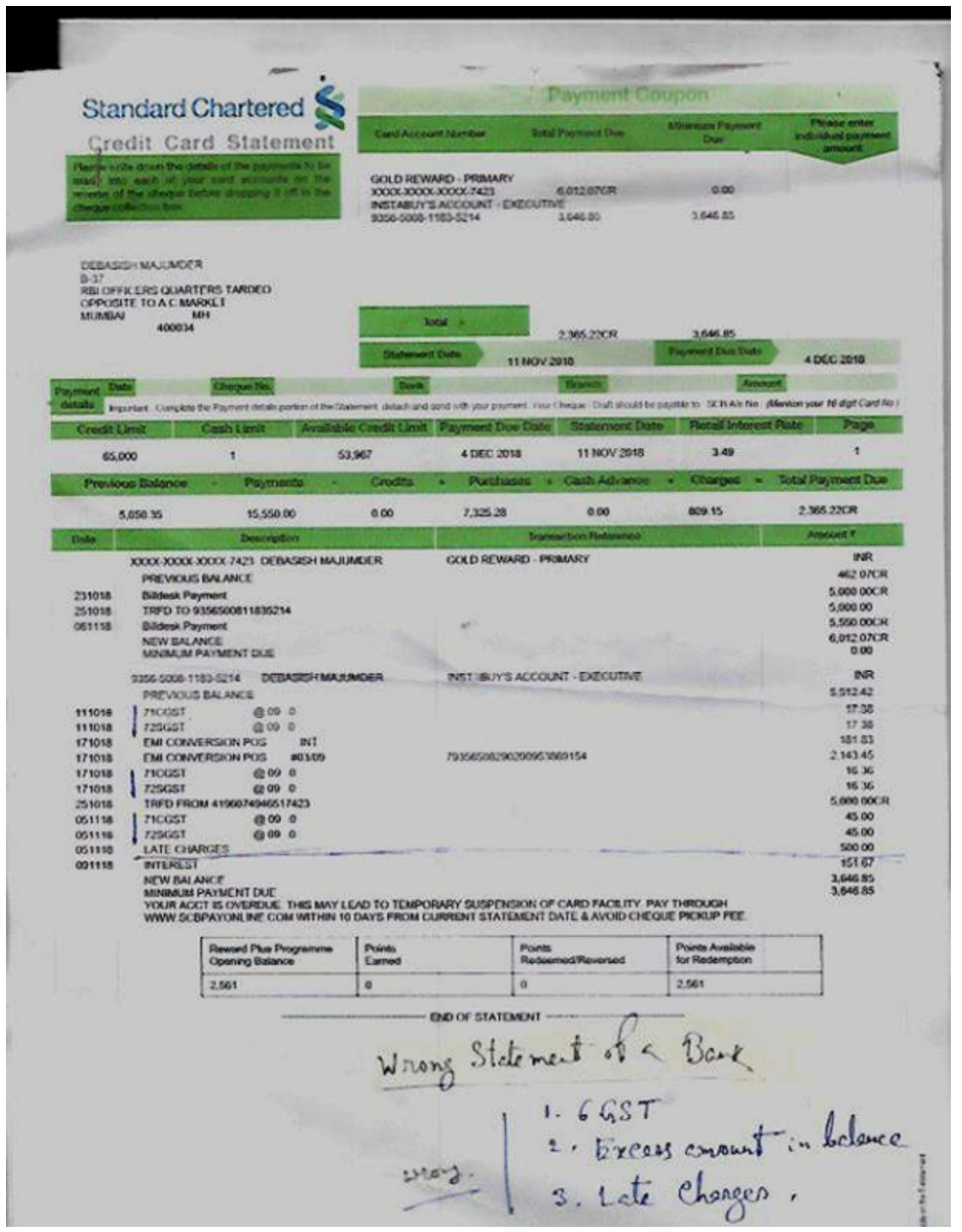

Figure 1. Wrong levy charges in credit card statement. Source: Standard Chartered credit card statement preserved by the author.

\section{Prof. Debasish Majumder (Date: March 31, 2021, Time: 3.40PM):}

Prof. Majumder was a political economist and preferred to teach subjects like economics, politics, etc. I wonder that she has a crazy, passionate love for politics and also for insane games viz., "bureaucratic game", "political game", "legal game", "evil game", etc. However, there is a serious difference between love and crazy love to the politics. Nevertheless, three important issues evolved from her speech: 1) all heads, leaders/CEOs/directors, are seniors belonging to the age-group of 50 - 80-is universally true, 2) invention of the vaccine was uncertain like every scientific invention and 3) technology had experienced a regime switch and traditional-aged economists/CEOs/leaders were semiliterate in that subject. I refer to the story of Archimedes who was depicted in history as the scientist ran naked through the street of Syracuse shouting "Eureka!"-or "I have it!". It is perhaps true that if the total national income of Germany in 1904 was given to a 
group of scientists and instructed to invent the theory of relativity in one year, the scientist group would have failed. Insight or creative mind is a vital element behind any scientific invention. Such inventive insight may begin with questions, doubt or a hunch. It may begin by recognizing that something unusual or accidental may be useful or that it could open a new avenue for exploration.

I support the fact that technology had experienced a regime switch during the last three years and also the researcher, who is skilled in the process of developing a mathematical model, commonly is not good in developing an algorithm in the programming environment to estimate that model and vice versa. I had a survey on optimization techniques available in the optimization toolbox in the three popular computational packages e.g., MATLAB, R and PYTHON. I found 27 types of different techniques are available. However, all these techniques are not appropriate for the empirical estimation of a particular type of econometric model. For example, greed search optimization is not recommended optimization technique for the Filtered Historical Simulation (FHS) model. However, sometimes results are wrong because researchers are not well-versed about the basics of optimization techniques. Sometimes technocrats are skilled in solving optimization, but are not good in economic modeling. For example, Figure 2 reports the methodology used in Roy (2011). The paper misinterpreted the theory of Filtered Historical Simulation (FHS) suggested by Barone-Adesi, Bourgoin, \& Giannopoulos (1998) in the line: 1) FHS combines best of MCS and best of HS and 2) samples are drawn with replacement from the residual series $\left\{\eta^{\wedge} t+1-\tau\right.$; $\tau=1,2 \ldots \mathrm{m}\}$, where $\eta$ is the GARCH residuals. The low quality paper used

\section{Filtered Iistorical Simulation (FIIS)}

As we have discussed that non-parametric approach such as $H S$ does not assume any statistical distribution of returns, whereas parametric approach such as the Monte Carlo simulation (MCS) takes the opposite view and assumes parametric models for variance, correlation (if a disaggregate model is estimated), and the distribution of standardised returns. Random numbers are then drawn from this distribution to calculate the VaR. Both of these extremes in the model-free/modelbased spectrum have pros and cons. MCS is good if the assumed distribution is fairly accurate in description of reality. HS is sensible as the observed data may eapture features of the returns distribution that sre not captured by any standard parametric model. The FHS appraach. on the other hand, attempts to combine the best of the MCS with the best of the HS.

Let us assume that we have estimaled a GARCH-type model of our portfolio variance given in equation (1). Although we may be comfortable with our variance model (o), we may not be comfortable in making a specific distributional assumption about the ( $\eta)$, such as a Normal or a $t$ distribution. Instead of that, we might like the past returns data $\left(r_{1}\right)$ to determine the distribution directly without making further assumptions.

Given a sequence of past returns and estimated GARCHwolatility. Tr, $\sigma_{t=1}, \tau=1.2 \ldots \mathrm{m}$; calculated past standardised returns are given by $\eta_{n+1-x}=\left(r_{n+1 .:}-E\left(r_{n+1-x}\right)\right) / \sigma_{n+1-x}: \tau=1.2 \ldots m$

Instead of drawing random $\eta$ 's from a specific probability distribution as it is done in MCS, in FIIS method samples are drawn

with replacement from $\left\{\eta_{, \ldots 1 . .,} \tau=1,2 \ldots \mathrm{m}\right\}$. Thereafter, we can get the hypathetical return of ' $t+k$ ' day as:

Figure 2. Snapshot from page 87 of Roy (2011). Source: Reserve Bank of India Occasional Paper, 2011, 32(2), 81-98. 
superscript as " $\wedge$ " which is commonly used in MATLAB/R programming languages and did not use bootstrapping (sampling with replacement) from the standardized residuals suggested by Barone-Adesi, Bourgoin, \& Giannopoulos (1998).

Never in a million years did high-profile seniors imagine that the rare disaster would happen in 2020. They were, therefore, not trained on how to execute an agreement/contract/MOU and improve the overall efficiency in a situation of extreme uncertainty and chaos in financial markets. It is undeniable that old age is not favorable to learn new things. These senior leaders misguided their fellow staffers/subordinates/clients into wallowing around with expenditure of the wrong sort, and thus they were not good leaders. They were the architects of discovering innovative ways for misuse of accumulated profits (or reserve) of their companies or wealth of the nation or economic output either by supporting wasteful works or through extremely dull policies or by peddling fundamentally flawed or low-quality research used for policymaking or by opaque bureaucratic or legal communications/circulars issued hastily during a period of stress. The economic recession of 2020-21 may be named as "recession due to age-related cognitive bias".

Prof. Neeta Majumder (Date: March 31, 2021, Time: 4.40 PM):

In a complex process of evolution, in a society undergoing an unprecedented change, we should not underestimate the role of a set of laws/accepted norms, accounting principles of macro-economic aggregates and post-event consistency checking. Moses, a legendary philosopher of ancient Israel, was the pioneer of the concept of the "torah", "law", or "teaching". The Book of Kings, a part of the Hebrew Bible, described "torah" or "law of Moses" as: "deuteronomy (any king and/or his officials) was considered supreme agency to set of laws, and the levites were the guardians and interpreters of the law". Unfortunately, Kings or supremos in 2020 did not imagine that the rare disaster would ever happen in 2020. Therefore, the set of norms implemented by them related to COVID-19 pandemic perhaps was not carefully considered or planned. I, however, strongly advise youngsters not to flout COVID-19 norms implemented by the law enforcement authorities. Under no circumstances, even though you feel depressed and frustrated because of your loved one was obliging COVID-19 norms of physical distancing and stopped cooking for you, do not send a legal notice to a celebrity or your boss for any of his/her previous "disgraceful" statement. Do not teach a lesson by using "foul words" as we remember William Shakespeare's quote, "Foul words is but foul wind, and foul wind is but foul breath, and foul breath is noisome; therefore I will depart". Do not publish derogatory rumors or cartoons/fabricated news in the popular social networking websites or newspapers. All these uncivilized acts flourished post-COVID-19 era, evidence of which was an increase of court cases for defamation during the great lockdown. These acts would possibly make you a COVID-19 intruder and my warning is for preventing students and junior faculties from becoming social bandits. Further, do not become a greedy young banker or profit hunter because short-term profits 
were earned through an "evil game" that is perhaps adverse to your reputation and also the reputations of your prestigious institution. Thank you all. We may call it a day.

\section{Conclusions, Revisiting Policies during 2010-2021, and recommendations}

There were many causes of the economic recession of 2020-21 delineated in contemporary research papers/publications by academicians, market researchers and regulatory policymakers. We, however, should not lose focus in the sea of numerous causes of the recession. The objective of the present paper is more specific, "Were supervisory or regulatory prescriptions and monetary policy recommendations after the financial crisis of 2007-08 self-referential processing or influenced by the previous recession's debilitating impacts?". The malign and provocative trend in the economic theory since 2010 was on the two directions: 1) progressively defensive/conservative stance in policy researches/policy prescriptions by the Government/the central bank/sectoral regulators and 2) the government/public sector employees were reluctant to do their work during the great lockdown. Going towards the more and more defensive path in the policymaking front, for example, an unconventional monetary policy for "permanent" monetization of budget deficits, frequent interventions in FOREX markets, imposing prohibitions and restrictions in export/import, implementation of Basel III without deep researches and stress tests, the conservative selection of the risk tolerance level for Value-at-Risk (VaR) and Expected Shortfall (ES), etc., which were implemented in the spirit of promoting sound regulatory risk management system or obtaining stability in the financial system, had not been supportive to corporate profitability and also to the national income. On some occasions, the conservative choice of the risk tolerance level calibrated substantially high market risk capital, which was baleful to an investment bank. Additionally, higher administrative costs and escalated legal costs after February 2020 were adverse to the bank's profitability. In the case of commercial banks in India, for example, regulatory requirements of Cash Reserve Ratio (CRR) was at 3.5\% and Statutory Liquidity Ratio (SLR) was at $18 \%$ of net demand and time liabilities (NDTL), BASEL III capital requirements namely capital conservation buffer was at $6.25 \%$ of risk-weighted assets (RWAs) up to September 30, 2021, reduced to $2.5 \%$ of risk-weighted assets (RWAs) from September 30, 2020 to April 1, 2021. The pre-specified trigger for loss absorption through conversion/write-down of Additional Tier 1 instrument (Perpetual Non-Convertible Preference Shares and Perpetual Debt Instruments) was at 5.5\% of risk-weighted assets (RWAs) and has been increased to $6.125 \%$ of RWAs from April 1, 2021. Capital adequacy requirements are at $9 \%$ of RWA. Additionally, $40 \%$ of Adjusted Net Bank Credit (ANBC) is the target set under priority sector lending. These credits were subsidized and the past record of repayment was also poor. When commercial banks abide by these stringent regulations, resources that utilize for profit-making pur- 
poses are to be calculated at less than $12 \%$ of NDTL. Regulations/policies implemented for managing the black swan risk were adverse to banks' profitability. The government/public sector employees did not do justice to their work during the prolonged lockdown. Policymakers were more inclined into event management that created a favorable environment for immoral employees to frame excuses. Immoral attitude of employees in the government/public sector and favorable circumstances to frame excuses for neglecting work distorted the smooth-running of a business. If there remains a large segment of the active workforce whose marginal contribution to the firm's profit was insignificant, the phenomenon would be disguised unemployment in the sector. Financial fragility has been induced primarily due to 1) disguised unemployment in the government/public sector and its domino effect, 2) in-group favoritism and also in-group fiscal support, 3) hankering for profits by young greedy bankers and 4) data inconsistency that occurred because of policies architected for the purpose of managing the rare disaster.

Revival from the crisis might be through progressive innovative researches in the areas, e.g., monetary policy, fiscal policy, financial risk management, accounting, etc. The following topics may be included: 1) consistency checking of the accounting of macro-economic aggregates, viz., national account statistics, balance of payment statistics, monetary statistics and fiscal statistics by constructing consistency accounting matrix (Rao, Samant, \& Asher, 1999) and 2) low-probability and high-impact tail events (or black swan events)are outliers in the data set and are commonly not captured by any known parametric or nonparametric statistical data generating model.

\section{Acknowledgements}

I am indebted to Prof. Romar Correa, Ex-Professor in Economics, University of Mumbai, Mumbai, India and Prof. Kalyan Das, Associate Professor in Economics, A.C. College of Commerce, Jalpaiguri, West Bengal, India for their valuable comments and discussions.

\section{Conflicts of Interest}

The author declares no conflicts of interest regarding the publication of this paper.

\section{References}

Bańbura, M., \& Giannone, D. (2013). Now-Casting and the Real-Time Data Flow. Frankfurt am Main: European Central Bank, Working Paper Series S No. 1564. https://doi.org/10.1016/B978-0-444-53683-9.00004-9

Barone-Adesi, G., Bourgoin, F., \& Giannopoulos, K. (1998). Don't Look Back. Risk, 11, 100-103.

Berkowitz, J., \& O’Brien, J. (2002). How Accurate Are Value-at-Risk Models at Commercial Banks? Journal of Finance, 57, 1093-1111. https://doi.org/10.1111/1540-6261.00455 
Bulletin, Reserve Bank of India (2020a). Demystifying Equity Prices Using Dividend Discount Model: An Indian Context (pp. 123-132). October, 2020.

Bulletin, Reserve Bank of India (2020b). Liquidity Management in the Time of Covid-19: An Outcomes Report (pp. 15-34). July, 2020.

BusinessLine (2020). Govt Restricts Export of 26 Drug Formulations. March 03, 2020.

Choraia, R., \& Das, A. (2021). Political Economy of Relative Inflation. The Hindu Business Line.

Correa, R. (2020). Central Bank Profits in National Accounts. Economic and Political Weekly, 25, 21-23.

Fox, H. C., Tuit, K. L., \& Sinha, R. (2013). Stress System Changes Associated with Marijuana Dependence Increase Craving for Alcohol \& Cocaine. Human Psychopharmacology, 28, 40-53. https://doi.org/10.1002/hup.2280

Gopinath, G. (2020a). The Great Lockdown: Worst Economic Downturn since the Great Depression. The Daily Tribute, April 15, 2020.

Gopinath, G. (2020b). Covid-19 Crisis Exacerbates Globalisation Worries. Deccan Herald, June 25, 2020.

Hausmann, R. (2014). Venezuela before Chavez: Anatomy of an Economic Collapse. University Park, PA: Pennsylvania State University Press. https://doi.org/10.1515/9780271064628

Holsti, O. R. (1962). The Belief System and National Images: A Case Study. The Journal of Conflict Resolution, 6, 244-252. https://doi.org/10.1177/002200276200600306

Kennedy, S., \& Dodge, S. (2020). How Unconventional Monetary Policy Turned Conventional. BloombergQuint.

Majumder, D. (2016). Value-at-Risk-Is It a Better Alternative to BASEL's Rule Based Strategy? Journal of Contemporary Management, 5, 71-85.

Majumder, D. (2018). Value-at-Risk Based on Time-Varying Risk Tolerance Level. Theoretical Economics Letters, 8, 111-118. https://doi.org/10.4236/tel.2018.81007

Marshall, A. (1890). Principles of Economics, London: Macmillan.

McElroy, R. G., \& Williams, G. (1941). The Coronation Cases-I. Modern Law Review, 4, 241-260. https://doi.org/10.1111/j.1468-2230.1940.tb00777.x

Mint (2020). RBI Only Central Bank to Set Up Quarantine Facility for Continued Services: Guv Das.

Mishra, P. K. (2020). COVID-19, Black Swan Events and the Future of Disaster Risk Management in India. Progress in Disaster Science, 8, Article ID: 100137.

https://doi.org/10.1016/j.pdisas.2020.100137

Mishra, P., \& Rajan, R. (2016). Rules of the Monetary Game. WPS (DEPR): 04/201.

Nachimuthu, K., \& Veni, M. (2019). Impact of Non-Performing Assets on the Profitability in Indian Scheduled Commercial Banks. African Journal of Business Management, 13, 128-137. https://doi.org/10.5897/AJBM2018.8683

Rajan, R. (2010). Fault Lines: How Hidden Fractures Still Threaten the World Economy. Princeton, NJ: Princeton University Press. https://doi.org/10.1515/9781400839803

Rao, M., Samant, A. P., \& Asher, N. L. (1999). Indian Macro-Economic Data Base in a Consistency Accounting Framework (1950-51 to 1997-98)-Identifying Sectoral and Economy Wide Budget Constraints. Economic and Political Weekly, 34, 2243-2262.

Roy, I. (2011). Estimating Value at Risk (VaR) Using Filtered Historical Simulation in the Indian Capital Market. Reserve Bank of India Occasional Paper, 32, 81-98. 
Schluter, M. (1994). The Rise and Fall of Nations: How Far Can Christians Interpret History. Cambridge Papers, 3 September 1994.

Singh, A. (2019). How Effective is RBI's Monetary Policy Transmission. Business Today.

Stolle, D., \& Harell, A. (2013). Social Capital and Ethno-Racial Diversity: Learning to Trust in an Immigrant Society. Political Studies, 61, 42-66. https://doi.org/10.1111/j.1467-9248.2012.00969.x

Subramanian, A. (2019). India's GDP Mis-Estimation: Likelihood, Magnitudes, Mechanisms, and Implications. CID Faculty Working Paper No. 354.

Taylor v Caldwell (1863). EWHC J1 (QB), 3 B \& S 826, 122 ER 309, Court of Queen's Bench.

The Economic Times (2019). Provision Coverage Ratio of Banks Has Improved to More than 70\%. The Economic Times, Nov. 25, 2019.

The Economic Times (2021). India's Export Restrictions, Import Duties on Farm Goods, Reforms Come Up in WTO Review. The Economic Times, Jan. 7, 2021.

The Economist (2019). Tech's Raid on the Bank: Digital Disruption Is Coming to Banking at Last (p. 9). The Economist, May 4, 2019.

The Times of India (2020). Private Details of 73 Lakh Indians Exposed in BHIM Data Leak, NPCI Issues Denial. The Times of India, June. 1, 2020.

Wise, A., \& Noble, G. (2016). Convivialities: An Orientation. Journal of Intercultural Studies, 37, 423-431. https://doi.org/10.1080/07256868.2016.1213786 